\title{
ANALISA KINERJA KEUANGAN 34 PROVINSI INDONESIA DI TAHUN 2018
}

\author{
Harsono Yoewono \\ Tanri Abeng University \\ Jl. Swadarma Raya No.58, Ulujami, Pesanggrahan, Jakarta, Indonesia
}

\begin{abstract}
Power sharing and delegation is politics in nature. The economic side appears on the regional budget planning and realisation. It is the mechanics and the setting of general policy, priority, and plafond of temporary budget. The latent fiscal gap occurs when revenues collected are lesser than expenditures spent, vice versa. Higher portion of expenditures posted as basic allocation has not been coped well with steady regional income. Supports in terms of better capability and capacity to collect regional revenues appear to be non-existent and meaningless, but the resource-rich regions. Even so, the central government appears to have big and deep impacts on the definition of taxable objects and types, and local retributions. This study is to seek which financial performance indicators that can be well-predicted by a numerous variables and indicators forming the regional budgets (APBD) of 34 provinces in Indonesia in 2018. The data was collected from DJPK website in early May 2019. The research method is quantitative descriptive in nature, and using both the OLS regression and determinant regression analysis. Based on the research of recent studies, a numerous financial performance indicators were derived as dependent variables, along with the variables forming the regional budgets of 34 provinces in Indonesia as independent variables. Sixteen dependent variables were set, whilst the 48 independent variables comprised of 4 groups, that is 4 variables of regional specific $\left(r_{-} \#\right), 23$ variables of revenues (y_\#), 9 variables of expenditures (c_\#), and 12 variables of finance/fiscal (f_\#). Upon the results of OLS linear regression, 3 variables of financial performance appeared to be the most significant and appealing than the rest. They were independence (k_08), the ratio of DAU in TKDD to the DAU Formula (k_16), dan decentralisation ( $\left.\mathrm{k}_{-} 10\right)$. On the contrary, 3 variables of financial performance appeared to have no determining variables. They were PAD growth (k_14), fiscal soundness and regional financial management (k_03), dan effectiveness
\end{abstract}


(k_11). These 3 variables were a part of 4 variables having the least adjusted $\mathrm{R}^{2}$, with infrastructure (k_04) as the remaining one. The heteroscedastic nature that appears in the $\mathrm{k} \_14$ estimation equation has suggested that $\mathrm{k} \_14$ fails to be used as the benchmark and reference of financial performance of regional budgeting, at least in its definition and operationalisation in this study and research. Likewise the usage of f_07 variable, the fiscal gap 1, the difference of DAU Formula with basic allocation (in basic data source).

Keywords: decentralisation, autonomy, financial performance, regional budget, good governance, government transfers

\section{PENDAHULUAN}

Desentralisasi kekuasaan pernah menjadi isu yang mengemuka setidaknya di 2 periode, yakni pada masa PRRI/Permesta (1956-1958) dan krisis moneter (1997/1998).Di tahun 1950-an, kesenjangan pembangunan ekonomi di daerah dan perlakuan tidak menyenangkan terhadap personel militer aktif dan purna-aktif membuat beberapa petinggi militer aktif mendeklarasikan pembentukan 4 Dewan Militer dan PRRI/Permesta. ${ }^{1}$

Di awal era reformasi, desentralisasi dan delegasi kekuasaan menjadi tema dan fokus legislasi, seperti terkait pemda, parpol, pilkada, susduk DPR, DPRD, dan DPD, perimbangan keuangan, pembagian urusan, dan lainnya. Aspek yang diatur mencakup penyelenggaraan, pelaporan, pertanggungjawaban, pembinaan, pengawasan, standarisasi, evaluasi, pengembangan kapasitas, dan lainnya.

Berbagai kewenangan, hak, dan kewajiban pemerintah daerah tertuang dalam bentuk rencana kerja pemerintahan daerah (RKPD) dan dijabarkan dalam bentuk pendapatan, belanja, dan pembiayaan daerah (APBD) yang dikelola dalam sistem pengelolaan keuangan daerah. Pengelolaan keuangan daerah dilakukan secara efisien,

\footnotetext{
${ }^{1}$ Penciutan peran Divisi X Banteng (semacam KOREM) menjadi Brigade, Resimen Infanteri 4, dan terakhir dilebur kedalam Kotter-I BB (Komando Tentara Teritorium I Bukit Barisan) menjadi awal terbentuknya 4 Dewan Militer dan Deklarasi PRRI/Permesta. Dewan Banteng oleh Letkol Ahmad Husein di Padang per 20.12.1956; Dewan Gajah oleh Kolonel Maludin Simbolon di Medan per 22.12.1956; Dewan Garuda oleh Letkol Barlian di Palembang pada pertengahan Januari 1957; Piagam Permesta oleh Letkol Ventje Sumual di Makassar per 02.03.1957; PRRI di Padang per 15.02.1958, dan Dewan Manguni oleh Mayor Daniel Julius Somba (Kepala Staf Kodam/KDM-SUT (Sulutteng)) di Manado per 17.02.1958.
} 
efektif, transparan, akuntabel, tertib, adil, patut, dan taat pada peraturan perundangundangan.

Walau diberikan kewenangan masing-masing untuk mengatur dan mengurus kepentingan masyarakat setempat serta menyalurkan aspirasi masyarakat menurut prakarsa sendiri, pemda tidak memiliki kewenangan dalam hal politik luar negeri; pertahanan; keamanan; yustisi (peradilan); moneter dan fiskal nasional; dan agama. Selain itu, setiap pemda berdiri sendiri dan tidak mempunyai hubungan hierarki satu sama lain.

Pembangunan daerah pun tidak terbatas pada aspek fisik seperti fasilitas sosial dan fasilitas publik yang layak, tetapi juga pada aspek hidup dan kehidupan manusia dan kemanusiaan.Perlindungan dan peningkatan kualitas kehidupan masyarakat diwujudkan dalam bentuk peningkatan pelayanan dasar, pendidikan, penyediaan fasilitas pelayanan kesehatan, dan pengembangan sistem jaminan sosial.

Pembiayaan pembangunan daerah dilakukan melalui mekanisme dan penetapan kebijakan umum dan prioritas APBD serta Plafon Anggaran Sementara.Beberapa pertimbangan yang umum mencakup analisis standar belanja, standar harga, tolok ukur kinerja, dan standar pelayanan minimal (SPM) yang ditetapkan sesuai dengan peraturan perundang-undangan.

Beberapa masalah yang umum terjadi pada manajemen keuangan daerah meliputi:

1. Kesenjangan fiskal yang lebar antara penerimaan yang sedikit dengan pengeluaran yang besar.

2. Kebutuhan fiskal yang belum bisa ditopang dengan kemampuan dan kapasitas daerah dalam mengelola penerimaan dan pengeluaran.

3. Masih tingginya alokasi dasar (biaya aparatur sipil negara).

4. Masih besarnya peran dan intervensi pemerintah pusat dalam penentuan objek dan jenis pajak serta retribusi daerah (Triastuti et al, 2005).

\section{TINJAUAN PUSTAKA}

\subsection{Otonomi Daerah}

Suatu daerah dibentuk atas pertimbangan kemampuan ekonomi, potensi daerah, sosial-budaya, sosial-politik, jumlah penduduk, luas daerah, dan lainnya.Bentuknya bisa 
berupa penggabungan dan/atau pemekaran wilayah.Beberapa syaratnya mencakup halhal administratif, teknis, dan fisik kewilayahan.Salah satu tujuan pembentukan daerah adalah terselenggaranya otonomi daerah.

Bentuk otonomi bisa formal, riel, atau material.Daerah tidak memiliki otonomi formal dalam politik luar negeri; pertahanan; keamanan; yustisi (peradilan); moneter dan fiskal nasional; dan agama.Di luar otonomi formal, kewenangan yang diberikan oleh pemerintah pusat menjadi kewenangan daerah otonom.

Suatu daerah memiliki otonomi riel ketika kewenangan yang diberikan oleh pemerintah pusat didasarkan pada kemampuan asli dan nyata dari daerah tersebut.Bentuk otonomi riel dinyatakan dalam laporan PAD.Kewenangan daerah yang dirinci dan diuraikan secara eksplisit disebut otonomi material.

Tiga aspek utama dalam implementasi otonomi daerah meliputi desentralisasi, dekonsentrasi, dan tugas pembantuan (pemerintah pusat yang dilaksanakan pemda untuk kepentingan daerah setermpat). Beberapa kepentingan daerah mencakup (Mardiasmo, 2002):

1. Peningkatan kualitas dan kuantitas pelayanan publik dan kesejahteraan masyarakat.

2. Terciptanya efisiensi dan efektivitas pengelolaan sumber daya daerah.

3. Pemberdayaan dan terciptanya ruang bagi masyarakat/publik untuk berpartisipasi dalam proses pembangunan.

\subsection{Kewenangan Daerah}

Setiap pemda diberikan kewenangan masing-masing untuk mengatur dan mengurus kepentingan masyarakat setempat menurut prakarsa sendiri berdasarkan aspirasi masyarakat. Setiap pemda berdiri sendiri dan tidak mempunyai hubungan hierarki satu sama lain. Walau demikian, pemda tidak memiliki kewenangan dalam politik luar negeri; pertahanan; keamanan; yustisi (peradilan); moneter dan fiskal nasional; dan agama.

Kewenangan pemda menurut UU No.32/2004 adalah sebagai berikut:

1. perencanaan dan pengendalian pembangunan;

2. perencanaan, pemanfaatan, dan pengawasan tata ruang;

3. penyelenggaraan ketertiban umum dan ketenteraman masyarakat;

4. penyediaan sarana dan prasarana umum;

5. penanganan bidang kesehatan; 
6. penyelenggaraan pendidikan dan alokasi sumber daya manusia potensial;

7. penanggulangan masalah sosial;

8. pelayanan bidang ketenagakerjaan;

9. fasilitasi pengembangan koperasi, usaha kecil, dan menengah;

10. pengendalian lingkungan hidup;

11. pelayaran pertanahan;

12. pelayanan kependudukan, dan catatan sipil;

13. pelayanan administrasi umum pemerintahan;

14. pelayanan administrasi penanaman modal;

15. penyelenggaraan pelayanan dasar lainnya; dan

16. urusan wajib lainnya yang diamanatkan oleh peraturan perundang-undangan.

Terkait pengelolaan dan pemanfaatan SDA, pemda diberikan kewenangan dan tanggung jawab dalam hal pemeliharaan, pengendalian dampak, budidaya, pelestarian; penyerasian lingkungan dan tata ruang serta rehabilitasi lahan.Khusus untuk sumber daya laut, pemda diberikan kewenangan untuk melakukan eksplorasi, eksploitasi, konservasi, pengelolaan kekayaan laut; pengaturan administratif; penegakan hukum, berpartisipasi dalam pemeliharaan keamanan dan pertahanan kedaulatan negara.

\subsection{Hak dan Kewajiban Daerah}

Dalam menyelenggarakan otonomi, daerah mempunyai hak:

1. mengatur dan mengurus sendiri urusan pemerintahannya;

2. memilih pimpinan daerah;

3. mengelola aparatur daerah;

4. mengelola kekayaan daerah;

5. memungut pajak daerah dan retribusi daerah;

6. mendapatkan bagi hasil dari pengelolaan sumber daya alam dan sumber daya lainnya yang berada di daerah;

7. mendapatkan sumber-sumber pendapatan lain yang sah; dan

8. mendapatkan hak lainnya yang diatur dalam peraturan perundang-undangan.

Dalam menyelenggarakan otonomi, daerah mempunyai kewajiban:

1. melindungi masyarakat, menjaga persatuan, kesatuan dan kerukunan nasional, serta keutuhan NKRI;

2. meningkatkan kualitas kehidupan masyarakat; 
3. mengembangkan kehidupan demokrasi;

4. mewujudkan keadilan dan pemerataan;

5. meningkatkan pelayanan dasar pendidikan;

6. menyediakan fasilitas pelayanan kesehatan;

7. menyediakan fasilitas sosial dan fasilitas umum yang layak;

8. mengembangkan sistem jaminan sosial;

9. menyusun perencanaan dan tata ruang daerah;

10. mengembangkan sumber daya produktif di daerah;

11. melestarikan lingkungan hidup;

12. mengelola administrasi kependudukan;

13. melestarikan nilai sosial budaya;

14. membentuk dan menetapkan peraturan perundang-undangan sesuai dengan kewenangannya; dan

15. kewajiban lain yang diatur dalam peraturan perundang-undangan.

Berbagai hak dan kewajiban daerah diwujudkan dalam bentuk rencana kerja pemerintahan daerah (RKPD) dan dijabarkan dalam bentuk pendapatan, belanja, dan pembiayaan daerah (APBD) yang dikelola dalam sistem pengelolaan keuangan daerah.Pengelolaan keuangan daerah dilakukan secara efisien, efektif, transparan, akuntabel, tertib, adil, patut, dan taat pada peraturan perundang-undangan.

\subsection{Fungsi dan Struktur APBD}

Menurut Permendagri No.13/2006, beberapa fungsi APBD mencakup hal-hal berikut:

1. Fungsi Otorisasi. Anggaran Daerah (AD) merupakan dasar untuk melaksanakan pendapatan dan belanja pada tahun yang bersangkutan.

2. Fungsi Perencanaan. AD merupakan pedoman bagi manajemen dalam merencanakan kegiatan pada tahun yang bersangkutan.

3. Fungsi Pengawasan. AD menjadi pedoman untuk menilai apakah kegiatan penyelenggaraan pemerintah daerah sesuai dengan ketentuan yang telah ditetapkan.

4. Fungsi Alokasi. AD diarahkan untuk mengurangi pengangguran dan pemborosan sumber daya serta meningkatkan efisiensi dan efektifitas perekonomian.

5. Fungsi Distribusi. AD harus mengandung arti/memperhatikan rasa keadilan dan kepatutan. 
6. Fungsi Stabilisasi. AD harus mengandung arti/harus menjadi alat untuk memelihara dan mengupayakan keseimbangan fundamental perekonomian.

Struktur APBD terdiri dari pendapatan, pengeluaran (belanja), dan pembiayaan.Belanja daerah menurut fungsi pengelolaan negara bertujuan untuk keselarasan dan keterpaduan pengelolaan keuangan negara. Beberapa aspek yang dicover APBD mencakup pelayanan umum; ketertiban dan keamanan; ekonomi; lingkungan hidup; perumahan dan fasilitas umum; kesehatan; pariwisata dan budaya; agama; pendidikan; serta perlindungan sosial.

\begin{tabular}{|c|c|c|}
\hline \multicolumn{3}{|c|}{ Tabel - Struktur APBD } \\
\hline Pendapatan Daerah & Pengeluaran (Belanja) Daerah & Pembiayaan Daerah \\
\hline$P A D$ & Belanja Tidak Langsung & Penerimaan \\
\hline Pajak daerah & Belanja Pegawai & SiLPA TA sebelumnya \\
\hline Retribusi daerah & Belanja Bunga & Pencairan dana cadangan \\
\hline $\begin{array}{l}\text { Hasil pengelolaan kekayaan daerah } \\
\text { yang dipisahkan }\end{array}$ & Belanja Subsidi & $\begin{array}{l}\text { Hasil Penjualan Kekayaan Daerah } \\
\text { yang Dipisahkan }\end{array}$ \\
\hline Lain-lain PAD yang sah & Belanja Bantuan sosial & Penerimaan Pinjaman Daerah dan \\
\hline & Belanja Bagi hasil kpd & Obligasi Daerah \\
\hline$D P$ & Prop/Kab/Kota dan Pemdes & Penerimaan Kembali Pemberian \\
\hline DBH pajak/bukan pajak & Belanja Bantuan keuangan kpd & Pinjaman \\
\hline DAU & Prop/Kab/Kota dan Pemdes & Penerimaan piutang daerah \\
\hline DAK & Belanja tidak terduga & $\begin{array}{l}\text { Penerimaan Kembali Investasi } \\
\text { Dana Bergulir }\end{array}$ \\
\hline Lain-lain pendapatan daerah yang & Belanja Langsung & Pengeluaran \\
\hline & Belanja Pegawai & Pembentukan Dana Cadangan \\
\hline Hibah & Belanja Barang dan Jasa & Penyertaan Modal (Investasi) \\
\hline Dana darurat & Belanja Modal & Daerah \\
\hline $\begin{array}{l}\text { DBH pajak dari Propinsi dan } \\
\text { Pemda lainnya }\end{array}$ & & $\begin{array}{l}\text { Pembayaran Pokok Utang } \\
\text { Pemberian Pinjaman Daerah }\end{array}$ \\
\hline $\begin{array}{l}\text { Dana penyesuaian dan otonomi } \\
\text { khusus }\end{array}$ & & \\
\hline $\begin{array}{l}\text { Bantuan keuangan dari Propinsi } \\
\text { atau Pemda lainnya }\end{array}$ & & \\
\hline Lain-lain & & \\
\hline Sumber: djpk.kemenkeu.go.id & & \\
\hline
\end{tabular}

Pajak daerah terdiri dari pajak kendaraan bermotor, pajak reklame, pajak hiburan, pajak hotel, bea balik nama. Retribusi daerah terdiri dari jasa parkir kendaraan, jasa angkut sampah, pelayanan pemakaman, retribusi pelelangan, retribusi izin trayek.Hasil pengelolaan kekayaan daerah yang dipisahkan berasal dari BUMD, pengelolaan SDA daerah, bank daerah, maupun pengelolaan swasta dengan kelompok masyarakat. 
Lain-lain PAD yang sah terdiri dari hasil penjualan kekayaan daerah yang tidak dipisahkan; hasil pemanfaatan atau pendayagunaan kekayaan daerah yang tidak dipisahkan; jasa giro; pendapatan bunga; tuntutan ganti rugi; keuntungan selisih nilai tukar rupiah terhadap mata uang asing; dan komisi, potongan, ataupun bentuk lain sebagai akibat dari penjualan dan/atau pengadaan barang dan/atau jasa oleh daerah.

\subsection{Akuntabilitas dalam Penetapan APBD}

APBD merupakan dasar pengelolaan keuangan daerah dalam masa 1 tahun anggaran terhitung mulai 1 Januari sampai dengan tanggal 31 Desember.Berdasarkan rencana kerja pemda (RKPD), Kebijakan Umum APBD (KUA) dan Prioritas dan Plafon Anggaran Sementara (PPAS) dalam rancangan APBD dibuat kepala daerah (KDH) yang dibantu TAPD (Tim Anggaran Pemda).

KUA dan PPAS merupakan acuan SKPD (Satuan Kerja Perangkat Daerah) dalam menyusun Rencana Kerja dan Anggaran (RKA) SKPD dengan pendekatan berdasarkan prestasi kerja yang akan dicapai.PPAS berisi program prioritas dan patokan batas maksimal anggaran yang diberikan kepada SKPD.RKA-SKPD kemudian diusulkan sebagai Rancangan Perda tentang APBD tahun berikutnya kepada DPRD untuk ditetapkan sebagai Perda APBD tahun berikutnya.

Pedoman penyusunan APBD yang ditetapkan Menteri Dalam Negeri memuat hal-hal berikut:

1. pokok-pokok kebijakan yang memuat sinkronisasi kebijakan pemerintah pusat dengan pemda;

2. prinsip dan kebijakan penyusunan APBD tahun anggaran berkenaan;

3. teknis penyusunan APBD; dan

4. hal-hal khusus lainnya.

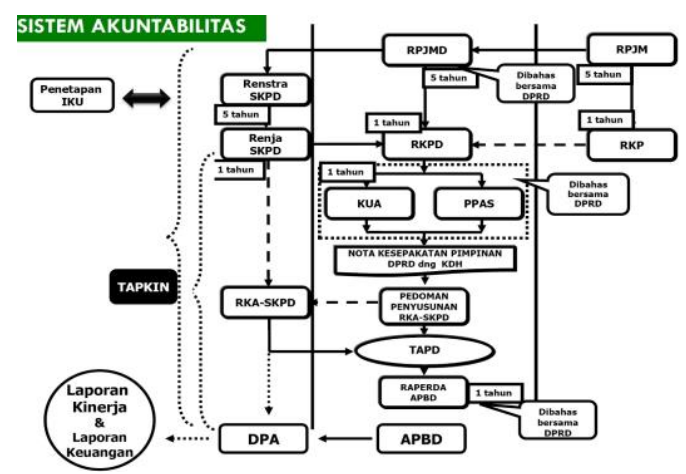


Bagan - Akuntabilitas dalam Penetapan APBD

Sumber: Ramliyanto, Penyusunan Indikator Kinerja Utama (IKU), 20131210.

RKA-SKPD disusun dengan pendekatan berdasarkan prestasi kerja yang akan dicapai. Indikator kinerja dibutuhkan sebagai ukuran keberhasilan atau kegagalan yang akan dicapai dari program dan kegiatan yang direncanakan atau ditargetkan. Termasuk didalamnya pengetahuan tentang faktor pendukung dan penghambat serta solusi yang mungkin terhadap permasalahan. Ukuran prestasi kerja yang akan dicapai bisa berwujud kualitas, kuantitas, efisiensi, dan efektivitas pelaksanaan dari setiap program dan kegiatan.

\subsection{Kinerja Keuangan Pemda}

Salah satu tujuan otonomi daerah adalah terciptanya kemandirian fiskal sekaligus menurunnya ketergantungan keuangan daerah terhadap pemerintah pusat dalam menjalankan roda pemerintahan.Termasuk didalamnya adanya indikator upaya desentralisasi yang nyata dan dilakukan pemerintah pusat.

Beberapa indikator kinerja keuangan daerah:

1. Kemandirian. Indikator otonomi fiskal merupakan rasio antara PAD dan Dana Perimbangan (DP). Tolok ukur (benchmark) yang biasa dijadikan acuan penilaian kemandirian dibagi kedalam 6 peringkat atau scoring, yakni sangat baik (0-10.00), baik (10.01-20), cukup (20.01-30), sedang (30.01-40), kurang (40.01-50), dan sangat kurang $(>50){ }^{2}$

2. Ketergantungan. Indikator ketergantungan merupakan rasio antara PAD dengan Total Penerimaan Daerah (TPD) tanpa subsidi (DP). Tolok ukur yang biasa dijadikan acuan dan penilaian ketergantungan dibagi kedalam 6 peringkat, yakni sangat rendah (0-10.00), rendah (10.01-20), sedang (20.01-30), cukup (30.01-40), tinggi (40.01-50), dan sangat tinggi $(>50){ }^{3}$ Indikator ketergantungan alternatif dihitung dengan membandingkan DP dengan TPD. ${ }^{4}$

3. Desentralisasi. Indikator desentralisasi merupakan rasio antara PAD dengan TPD.

Tolok ukur yang biasa dijadikan acuan dan penilaian desentralisasi dibagi kedalam

\footnotetext{
${ }^{2}$ Balitbang Depdagri - Fisipol UGM, Pengukuran Kemampuan Keuangan Daerah Tingkat II dalam rangka Otonomi Daerah Yang Nyata dan Bertanggung Jawab, Jakarta, 1991.

${ }^{3}$ Balitbang Depdagri - Fisipol UGM (1991).

4 Aswin Rizkiano, Pengukuran Tingkat Kemampuan Keuangan Daerah dalam Mendukung Pelaksanaan Otonomi Daerah Periode 2004-2008 di Kota Salatiga, 20110419.
} 
6 peringkat, yakni sangat kurang (0-10.00), kurang (10.01-20), sedang (20.01-30), cukup (30.01-40), baik (40.01-50), dan sangat baik (>50). ${ }^{5}$

4. Efektivitas. Indikator efektivitas merupakan rasio antara realisasi dan target PAD. Tolok ukur yang biasa dijadikan acuan dan penilaian efektivitas dibagi kedalam 5 peringkat, yakni sangat efektif (>100), efektif (90-100), cukup efektif (80-90), kurang efektif (60-80), dan tidak efektif $(<60){ }^{6}$

5. Efisiensi. Indikator efisiensi merupakan rasio antara pengeluaran dan penerimaan. Tolok ukur yang biasa dijadikan acuan dan penilaian efisiensi dibagi kedalam 5 peringkat, yakni tidak efisien (>100), kurang efisien (90-100), cukup efisien (80$90)$, efisien (60-80), dan sangat efisien $(<60){ }^{7}$

6. Keserasian. Indikator keserasian (aktivitas) merupakan rasio antara belanja tidak langsung dengan belanja langsung. Tolok ukur ini memperlihatkan kecenderungan semakin rendahnya belanja langsung pemda dalam penyediaan sarana dan prasarana ekonomi masyarakat. $^{8}$

7. Kemampuan Rutin. Indeks Kemampuan Rutin (IKR) merupakan rasio antara jumlah $(\mathrm{PAD}+\mathrm{DAU}+\mathrm{DBH})$ dengan belanja rutin. ${ }^{9}$

8. Kemampuan. Indeks Kemampuan Keuangan (IKK) daerah merupakan rata-rata jumlah 3 indeks PAD, yakni Indeks Pertumbuhan (XG), Indeks Pangsa (XS), dan Indeks Elastisitas (XE). XS dihitung sebagai rasio antara PAD dan TPD. XE dihitung sebagai rasio antara belanja langsung dan PAD. ${ }^{10}$ Tolok ukur yang biasa dijadikan acuan dan penilaian kemampuan keuangan daerah dibagi kedalam 3 peringkat, yakni rendah (0-0.33), sedang (0.34-0.43), dan tinggi (0.44-1). ${ }^{11}$

9. Kapasitas Fiskal PDRB. Indikator kapasitas fiskal PDRB merupakan rasio antara (PDRB/jumlah penduduk) dan kapasitas fiskal rata-rata daerah (standar). Kapasitas

${ }^{5}$ Balitbang Depdagri - Fisipol UGM (1991).

${ }^{6}$ Kepmendagri No.690.900.327 Tahun 1996.

${ }^{7}$ Kepmendagri No.690.900.327 Tahun 1996.

${ }^{8}$ Abdul Halim. Akuntansi Sektor Publik Akuntansi Keuangan Daerah, Salemba Empat. Jakarta. 2004.

${ }^{9}$ Rizkiano (2011).

${ }^{10}$ Balitbang Depdagri (1991); dalam Rizkiano (2011).

${ }^{11}$ BAPPENAS. Peta Kemampuan Keuangan Provinsi dalam Era Otonomi Daerah: Tinjauan Atas Kinerja PAD dan Upaya yang Dilakukan Daerah. Direktorat Pengembangan Otonomi Daerah. 2003; dalam Bisma dan Susanto (2010). 
fiskal rata-rata merupakan rasio antara (jumlah PDRB/penduduk) dengan jumlah Dati II. ${ }^{12}$

10. Kapasitas Fiskal APBD. ${ }^{13}$ Indikator kapasitas fiskal APBD merupakan jumlah PAD dan DBH. ${ }^{14}$ DAU berfungsi sebagai faktor pemerataan kapasitas fiskal. DAU suatu daerah dibuat atas dasar celah fiskal dan alokasi dasar. DAU nasional ditetapkan minimal sebesar $26 \%$ APBN.

11. Kebutuhan Fiskal Daerah merupakan kebutuhan pendanaan daerah untuk melaksanakan fungsi layanan dasar umum. Dasar kalkulasi pendanaan layanan dasar umum adalah jumlah penduduk, luas wilayah, Indeks Kemahalan Konstruksi, PDRB per kapita, dan IPM (Indeks Pembangunan Manusia). ${ }^{15}$

Indikator kebutuhan fiskal bisa disebut pula sebagai indeks pelayanan publik per kapita (IPPP).IPPP merupakan rasio antara PPP (pengeluaran aktual per kapita untuk jasa-jasa publik) dengan kapasitas fiskal standar $\left(\mathrm{KF}_{\mathrm{S}}\right){ }^{16}$

12. Celah Fiskal (fiscal gap).Indikator ini merupakan selisih antara kebutuhan fiskal dan kapasitas fiskal. ${ }^{17}$ Tolok ukur ini memperlihatkan kecenderungan terbalik antara semakin besar nilai celah fiskal dengan kemandirian (otonomi) keuangan daerah.

13. Ketidakseimbangan Vertikal (vertical imbalance). Indikator ini merefleksikan kecenderungan terbalik antara semakin besar belanja pemda dengan kemampuan pendanaan otonom (PAD). ${ }^{18}$ Indikator ini merupakan rasio antara transfer antar pemerintahan (TAP) dan total pengeluaran daerah (TPeD). ${ }^{19}$

Berbagai indikator kinerja pemda dibuat berdasarkan 5 kriteria, yakni input, proses, output, outcome, dan dampak. ${ }^{20}$ Faktor input mencakup SDM, waktu, uang, dan

\footnotetext{
${ }^{12}$ Sukanto Reksohadiprodjo, Ekonomika Publik, BPFE Yogyakarta. 2001.

${ }^{13}$ Triastuti et al (2005) gagal mendefinisikan PL dan BP sebagai unsur dalam penghitungan kapasitas fiskal APBD yang membagi jumlah (PAD+BH+DAU+PL-BP) dengan jumlah penduduk miskin. Pun dalam hal definisi dan dasar kalkulasi KKF, serta rekomendasi memasukkan DBH dalam penghitungan (indeks) kemandirian keuangan daerah. Maria Rosarie Harni Triastuti, Muhadjir Darwin, dan Ratminto, Analisis Kemandirian Keuangan Daerah Kota Yogyakarta (Studi tentang Desentralisasi dan Otonomi Fiskal Daerah), Sosiosains, 18 (2), April 2005.

${ }^{14}$ Pasal 28 ayat 3 , UU No.33/2004 tentang PKPD.

${ }^{15}$ Pasal 28, UU No.33/2004 tentang PKPD.

${ }^{16}$ Satija, Muhadjir Darwin, dan Ratminto, Kapasitas Keuangan Daerah Kabupaten Sleman, Sosiosains, 19 (3) Juli 2006.

${ }^{17}$ Pasal 27 ayat 3, UU No.33/2004 tentang PKPD.

${ }^{18}$ Anwar Shah dan Zia Qureshi, Intergovernmental Fiscal Relation in Indonesia: Issues and Reform Option, Discussion Paper, World Bank, 1994:49-53; dalam Satija et al (2006).

${ }^{19}$ Menurut Triastuti et al (2005), TAP didefinisikan sebagai transfer dari tingkatan lain pemerintahan nasional.

${ }^{20}$ Mohamad Mahsun. Pengukuran Kinerja Sektor Publik. BPFE, Yogyakarta, 2006.
} 
prasarana. Faktor proses mencakup unsur kecepatan, ketepatan, akurasi, efisiensi, efektivitas, ekonomis, dan prosedural. Faktor output bisa berupa fisik dan non-fisik dalam hal kuantitas dan ketepatan.

Faktor outcome mencakup hasil atau efek langsung yang diharapkan terjadi dalam jangka menengah dan melibatkan kepentingan banyak pihak.Sementara faktor dampak bisa berupa efek positif atau negatif dalam bentuk peningkatan kesejahteraan masyarakat, peningkatan pendapatan masyarakat, atau lainnya.

Alam dan SDM yang berbeda membuat setiap daerah memiliki ciri dan keunikannya masing-masing.Termasuk didalamnya hubungan antara pemerintah pusat dan pemda.Hamid memetakan hubungan antara pemerintah pusat dengan pemda kedalam 4 pola, yakni instruktif, konsultatif, partisipatif, dan delegatif. ${ }^{21}$ Pada hubungan instruktif, peran pusat lebih dominan dan pemda tidak mampu menjalankan otonomi secara mandiri.

Pada hubungan konsultatif, intervensi pusat sudah mulai berkurang dan daerah dianggap sudah sedikit lebih mampu menjalankan otonomi.Pada hubungan partisipatif, peran pusat semakin berkurang yang ditandai dengan semakin tingginya tingkat kemandirian daerah dalam menjalankan otonomi.Pada hubungan delegatif, pemda dianggap sudah mampu dan mandiri dalam menjalankan otonomi dan peran pemerintah terbatas pada urusan pendelegasian.

\subsection{Studi Terdahulu}

Studi tentang kinerja keuangan daerah mayoritas bersifat deskriptif terhadap indikator kinerja keuangan daerah yang diobservasi dan diteliti.Hanya sedikit penelitian yang menganalisa korelasi variabel pembentuk APBD terhadap variabel kinerja keuangan daerah. Penggunaan variabel bebas pun sangat terbatas. Korelasi yang diteliti dan dibahas pun hanya parsial.Kecuali disertasi Badrudin, wilayah penelitian pun terbatas untuk 1 Dati II atau Dati I.

\begin{tabular}{|c|c|c|c|c|c|c|c|c|c|c|c|c|c|c|c|c|c|c|c|c|}
\hline \multirow{2}{*}{ Peneliti } & \multirow{2}{*}{ Wilayah } & \multirow{2}{*}{ Periode } & \multicolumn{18}{|c|}{ Beberapa Indikator Kinerja Keuangan Daerah } \\
\hline & & & 1 & 2 & 3 & 4 & 5 & 6 & 7 & 8 & 9 & 10 & 11 & 12 & 13 & 14 & 15 & 16 & 17 & 18 \\
\hline Triastuti et al (2005) & Kota Jogja & $1998-2004$ & & & $\sqrt{ } \mathrm{c})$ & & & & & & & & & $\checkmark$ & $\checkmark$ & $\checkmark$ & & & $\checkmark$ & $\checkmark$ \\
\hline Satija et al (2006) & Sleman & 1998-2003 & & & $\sqrt{d})$ & & & & & & & & & $\checkmark$ & & $\checkmark$ & $\checkmark$ & $\checkmark$ & & \\
\hline Bisma dan Susanto (2010) & NTB & 2003-2007 & $\checkmark$ & $\checkmark$ & $\checkmark$ & $\checkmark$ & $\checkmark$ & & & $\checkmark$ & $\checkmark$ & $\checkmark$ & $\checkmark$ & & & & & & & \\
\hline Rizkiano (2011) & Salatiga & 2004-2008 & & $\sqrt{b})$ & va) & & & & $\checkmark$ & & $\checkmark$ & & & & & & & & & \\
\hline Ruslina Nadeak (2003) & Maluku & 1998-2002 & & & $\checkmark$ & $\checkmark$ & & & & & & & & & & & & & & \\
\hline
\end{tabular}

${ }^{21}$ Abdul Halim, Bunga Rampai Manajemen Keuangan Daerah. AMP YKPN. Yogyakarta, 2001:168169; dalam Ruslina Nadeak (Agnes Jeanette Nadeak), Analisis Rasio Keuangan APBD untuk Menilai Kinerja Pemerintah Daerah: Kasus pada Kabupaten Maluku Tenggara, Skripsi, Universitas Sanata Dharma, Yogyakarta, 2003, hal.20-21. 


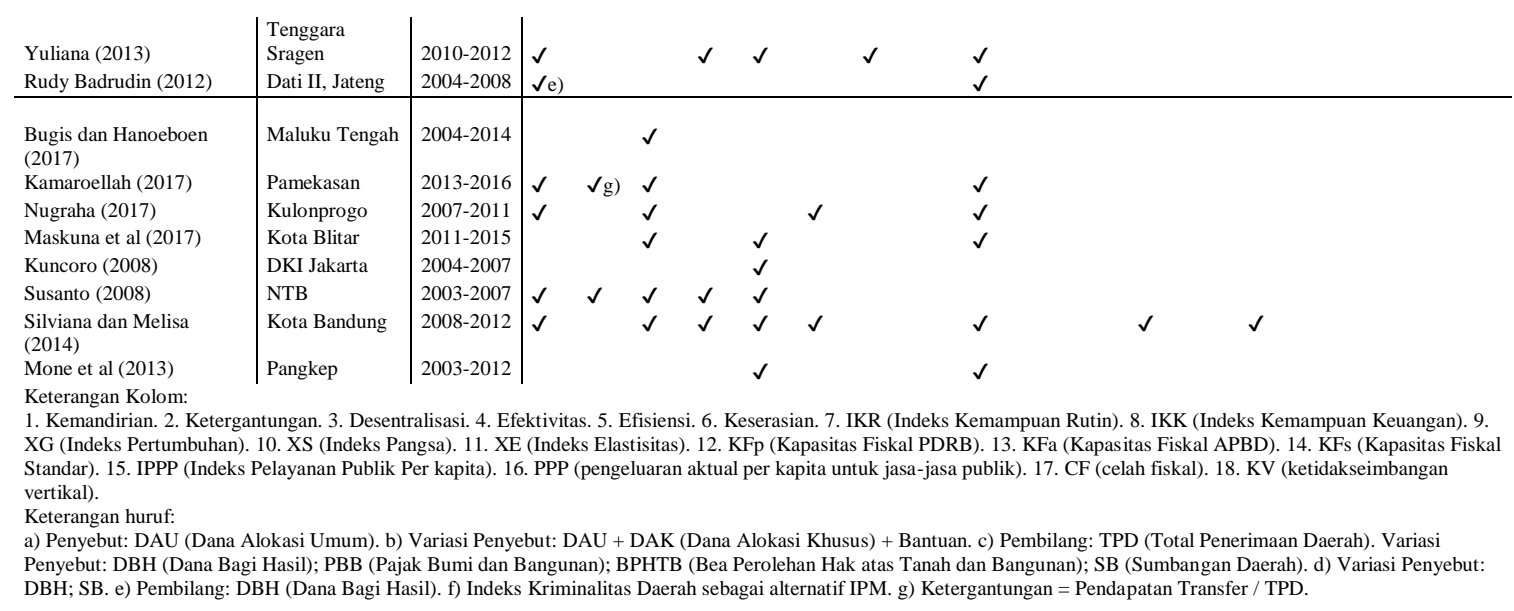

\subsection{Celah Penelitian}

Belum ada penelitian kinerja keuangan daerah yang mencakup keseluruhan provinsi di Indonesia, yakni sebanyak 34 provinsi.Demikian pula belum ada penelitian tentang korelasi antara variabel pembentuk APBD dengan berbagai indikator kinerja keuangan daerah.

\section{METODOLOGI PENELITIAN}

\subsection{Jenis Penelitian}

Analisa dalam penelitian ini bersifat kuantitatif deskriptif.

\subsection{Objek Penelitian}

Objek penelitian adalah variabel pembentuk APBD di 34 provinsi di tahun 2018. Data dikumpulkan dari situs web Ditjen Perimbangan Keuangan, Kementerian Keuangan di awal Mei 2019. ${ }^{22}$ Data pembentuk APBD terbagi atas 3 sumber kelompok, yakni data dasar, TKDD (Transfer ke Daerah dan Dana Desa), dan APBD.

\subsection{Pembentukan Model}

Berbagai indikator kinerja keuangan daerah menjadi variabel terikat.Estimasi berbagai indikator kinerja keuangan daerah merupakan fungsi berbagai variabel pembentuk APBD, yakni unsur wilayah (luas dan penduduk), penerimaan, pengeluaran (belanja), dan pembiayaan. Pernyataan matematis hubungan antara unsur pembentuk APBD dengan kinerja keuangan daerah dapat dirumuskan ke dalam persamaan berikut:

$$
\pi=f(\mathrm{R}, \mathrm{\Upsilon}, \mathrm{C}, \mathrm{F})
$$

dimana

\footnotetext{
${ }^{22}$ http://www.djpk.kemenkeu.go.id/portal/data/apbd
} 
$\pi=$ indikator kinerja keuangan daerah

$\mathrm{R}=$ ukuran spesifik wilayah

$\Upsilon=$ ukuran penerimaan dalam pembentukan APBD

$\zeta=$ ukuran pengeluaran (belanja) dalam pembentukan APBD

$\mathrm{F}=$ ukuran pembiayaan dalam pembentukan APBD

\section{Variabel Penelitian}

Kelompok Variabel Kinerja Keuangan Daerah

k_01 IKK

k_02 IPM

k_03 Kesehatan Fiskal \&Pengelolaan Keuangan

k_04 $\quad \begin{aligned} & \text { Daerah } \\ & \text { Infrastruktur }\end{aligned}$

k_05 Kesehatan

k_06 Pendidikan

$\begin{array}{lll}\text { k_07 } & & \text { Kesejahteraan Masyarakat } \\ \text { k_08 } & \text { PAD/DP }<\text { APBD }> & \text { Kemandirian }\end{array}$

k_09 PAD / (TPD-DP) <APBD> Ketergantungan

k_10 $\quad \mathrm{PAD} / \mathrm{TPD}<\mathrm{APBD}>\quad$ Desentralisasi (XS)

k_11 PAD realisasi / target $\langle$ APBD $>\quad$ Efektivitas

k_12 TPeD/TPD $<$ APBD $>\quad$ Efisiensi

k_13 BTL/BL <APBD> Keserasian

k_14 gPAD <data dasar $>\quad$ XG of PAD <data dasar $>$

$\mathrm{k} \_15 \quad \mathrm{BL} / \mathrm{PAD}<\mathrm{APBD}>\quad \mathrm{XE}$

k_16 DAU <TKDD> / DAUf

Kelompok Variabel Ukuran Spesifik Wilayah

r_01 Jiwa

Penduduk

r_02 km2

Luas Daratan

r $03 \quad \mathrm{~km} 2$

Luas Lautan

r_04 km2

Luas Wilayah

Kelompok Variabel Penerimaan dalam APBD

y_01

y_02 PAD_1

PDRB/capita

y_03 PAD_2

$\mathrm{PAD}<$ data dasar $>$

$\quad$ PAD $<A P B D>$

y_04 Pendapatan Lainnya $<$ APBD $>$

y_05 TPD $\langle$ APBD $>$

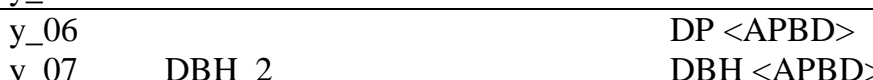

$\begin{array}{lll}\text { y_07 } & \text { DBH_2 } & \text { DBH }<\text { APBD }> \\ \text { y_08 } & \text { DBH 3 } & \text { DBH }<\text { TKDD }>\end{array}$

y_09 DBH_1 = DBHp_1+DBHa_1 DBH $<$ data dasar $>$

y_10 DBHp_3 DBH Pajak $\langle$ TKDD $>$

y_11 DBHa_3 DBH SDA <TKDD>

y_12 DBHp_1 DBH Pajak <data dasar>

y_13 DBHa_1 DBH SDA <data dasar $>$

y_14 DAK_2 DAK $<$ APBD $>$

y_15 DAK_3 DAK Fisik+Non-Fisik <TKDD>

$\begin{array}{ll}\mathrm{y} \_16 & \text { DAK Fisik }<\mathrm{TKDD}> \\ \mathrm{y} \_17 & \text { DAK Non-Fisik }<\mathrm{TKD} \text { > }>\end{array}$

y_17 DAK Non-Fisik <TKDD>

y_18 DID <TKDD>

y_19

y_20

Otsus + Keistimewaan $\langle$ TKDD $>$

y_21 DAU_1

Dana Desa <TKDD>

y_22 DAU_2

Alokasi DAU Formula

y_23 DAU_3

DAU <APBD>

Kelompok Variabel (Pengeluaran) Belanja dalam APBD

c_01

$\mathrm{TPeD}<\mathrm{APBD}>$ 


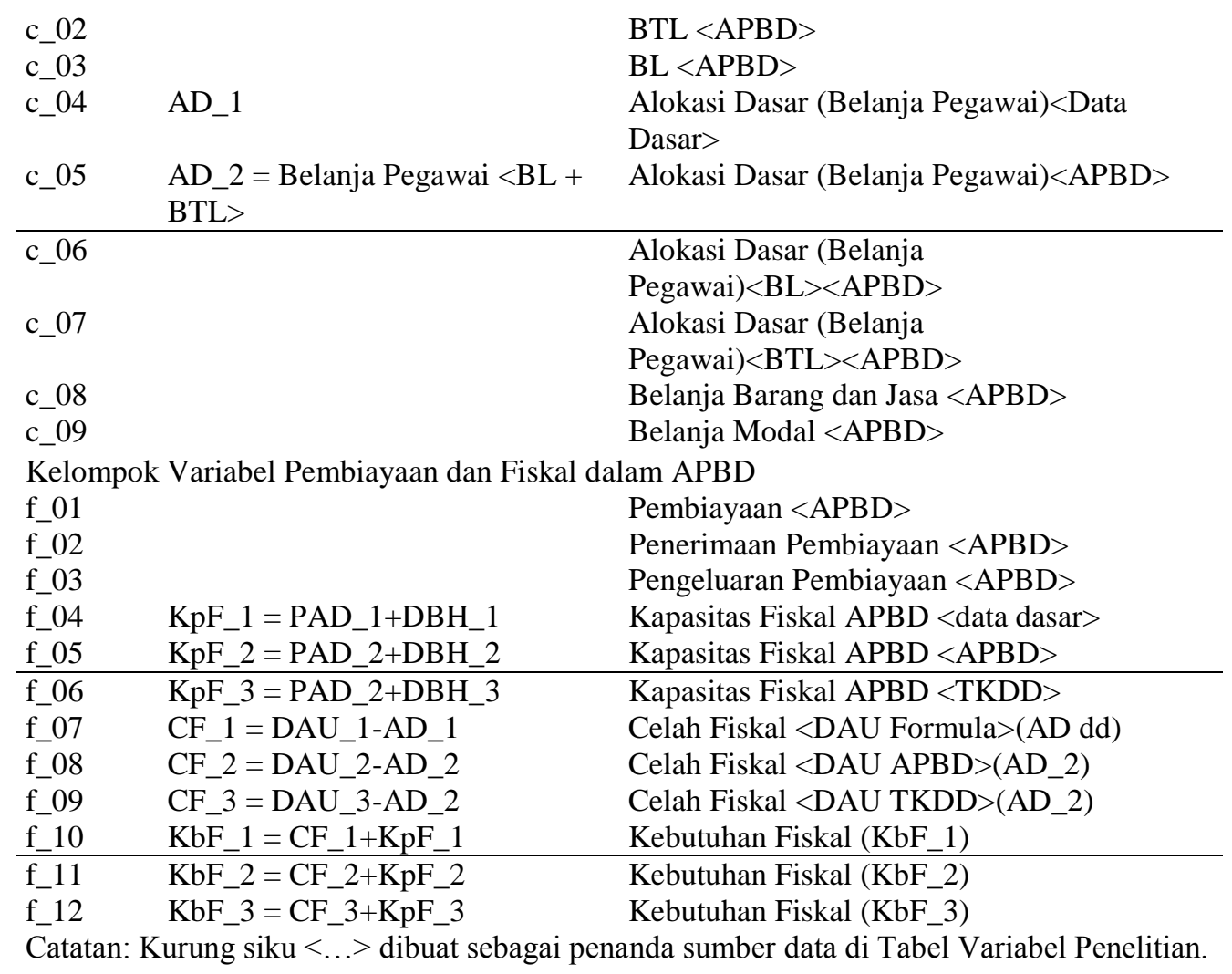

\subsection{Metode Analisa}

Pengolahan dan kalkulasi data dalam penelitian dilakukan dengan menggunakan program Microsoft Excel dan IBM SPSS. Pelanggaran asumsi klasik diuji untuk menentukan kelayakan dan kepantasan variabel dan/atau indikator dalam mengestimasi model dan/atau untuk menunjukkan ada/tidaknya kesalahan statistik. Beberapa uji pelanggaran asumsi klasik mencakup:

1. Uji Kolmogorov-Smirnov (distribusi normal data dan variabel).

2. Uji statistik parametrik dengan regresi linier ganda dan ANOVA (uji F).

3. Kalkulasi korelasi sebagai bukti regresi linier ganda.

4. Uji multikolinieritas.

5. Uji heterosedastisitas.

6. Uji otokorelasi.

7. Kesesuaian model (GoF, R2)

8. Uji-t.

Sebanyak 48 variabel bebas akan diuji efeknya terhadap berbagai indikator yang diasumsikan sebagai bentuk kinerja keuangan daerah, yakni dalam bentuk 16 variabel terikat yang ditandai dengan k_\#. Variabel bebas yang digunakan sebagai indikator 
untuk mengestimasi terbagi atas 4 kelompok, yakni unsur wilayah $\left(r_{-} \#\right)$, penerimaan dalam APBD (y_\#), pengeluaran (belanja) dalam APBD (c_\#), dan pembiayaan/fiskal (f_\#).

Banyaknya variabel bebas yang digunakan biasanya berdampak pada tingginya nilai korelasi, baik itu dalam bentuk R ataupun R2.Regresi determinasi dilakukan dalam rangka mencari variabel yang paling berperan dalam mengestimasi variabel yang ingin diprediksi. Indikator persamaan yang paling mendeterminasi biasanya sudah terlihat pada nilai adjusted $\mathrm{R} 2$.

Nilai adjusted R2 yang jauh terpuruk dari nilai R dan R2 secara tidak langsung memberikan sinyal minimnya variabel yang mendeterminasi dalam suatu persamaan yang ingin diestimasi.

\section{HASIL PENELITIAN}

\subsection{Nilai $N$}

Uji normalitas memperlihatkan bahwa lebih dari setengah variabel terikat (yakni 9 dari 16) yang ingin dibuatkan persamaan estimasinya ternyata tidak terdistribusi normal.Sementara pada variabel bebas, hanya 2 dari 48 variabel bebas memiliki nilai (dan statistik) yang tidak terdistribusi normal.Sembilan variabel terikat yang tidak terdistribusi normal adalah k_03, k_04, k_05, k_06, k_07, k_09, k_13, k_14, dan k_16.Dua variabel bebas yang tidak terdistribusi normal adalah r_04 dan y _06.

\subsection{Nilai $\mathrm{VF}$}

Dua kesamaan yang umum ada pada regresi linier (OLS) dalam rangka mencari persamaan untuk mengestimasi pengaruh 4 kelompok variabel terhadap 16 variabel kinerja sebagai variabel terikat adalah sebagai berikut:

1. Sebanyak 19 variabel bebas dikecualikan dalam perhitungan yang dilakukan SPSS. Ke-19 variabel yang dikecualikan dalam regresi linier OLS adalah r_o2, y_03, y_05, y_06, y_09, y_10, y_15, y_23, c_01, c_03, c_05, c_07, f_02, f_04, f_05, f_06, f_07, f_10, dan f_11.

2. Ke-16 persamaan estimasi variabel kinerja keuangan daerah semuanya bersifat multikolinieritas. Hal ini ditandai dengan semua VF bernilai lebih dari dari 10. Nilai toleransi dan VF dalam statistik kolinieritas pun identik di seluruh 16 persamaan hasil regresi.

\subsection{Nilai $F$}


Sebanyak 7 dari 16 persamaan regresi OLS bersifat tidak signifikan dalam memprediksi 16 variabel kinerja yang ingin diestimasi. Ke-7 variabel kinerja tersebut antara laink_03, k_04, k_05, k_06, k_07, k_11, dan $\mathbf{k} \_14$. Enam dari 7 variabel kinerja (diketik tebal) tersebut tidak terdistribusi normal, kecuali k_11.Sembilan variabel kinerja yang bisa diprediksi secara signifikan adalah k_01, k_02, k_08, k_09, k_10, k_12, k_13, k_15, dan k_16.

\subsection{Uji Heterosedastisitas}

Uji heterosedastisitas pada regresi linier tanpa konstanta (atau melalui titik 0), dilakukan dengan menempatkan nilai absolut dari residu unstandardisedpasca-regresi variabel kinerja $(\mathrm{k} \#)$ sebagai variabel terikat dan 48 variabel bebas sebagai predictornya.Inferensi ada/tidaknya heterosedastisitas melalui uji Gletsjer dilakukan dengan melihat nilai sig-t dari koefisien estimasi di variabel bebas.

Bila pada regresi linier OLS terdapat 19 variabel bebas yang dikecualikan, jumlah yang sama terjadi pula pada regresi nilai absolut dari residu unstandardised pasca-regresi variabel kinerja $(\mathrm{k} \#)$ sebagai variabel terikat. Perbedaannya terletak pada 4 variabel bebas sebagai predictor pada persamaan estimasi.

19 variabel bebas yang dikecualikan pada regresi nilai absolut dari residu unstandardised adalah sebagai berikut: r_04, y_03, y_05, y_06, y_08, y_09, y_15, y_21, y_22, y_23, c_01, c_03, c_05, f_02, f_04, f_05, f_06, f_10, f_11. Sebanyak 14 dari 16 persamaan estimasi ternyata memiliki nilai sig-t yang lebih besar dari 0,05.Dengan kata lain, ke-14 persamaan tersebut terbukti tidak melanggar asumsi klasik, yakni pada aspek adanya heterosedastisitas.

Di sisi lain, pelanggaran asumsi klasik terjadi pada 2 persamaan estimasi, yakni dengan abs_rk14dan abs_rk15 sebagai variabel terikatnya. Pada persamaan estimasi dengan abs_rk14 sebagai variabel terikatnya, 2 variabel bebas (y_01 dan f_07) memiliki sig-t kurang dari 0,05 (masing-masingnya 0,010 dan 0,009).Pada persamaan estimasi dengan abs_rk15 sebagai variabel terikatnya, hanya 1 variabel bebas (f_07) memiliki sig-t kurang dari 0,05, yakni sebesar 0,026.

Dengan kata lain, PDRB per kapita (y_01) dan Celah Fiskal I (selisih DAU formula dengan alokasi dasar/belanja pegawai di data dasar) (f_07) membuka adanya heterosedastisitas (pelangaran aumsi klasik) pada persamaan estimasi abs_rk14 (nilai absolut residu unstandardised pada regresi linier dalama estimasi pertumbuhan PAD). 
Pun pada persamaan estimasi k_14 sebagai variabel terikat, adjusted $\mathrm{R}^{2}$ bernilai negatif dan F-stat yang bernilai 0,333. Bila dicermati lebih lanjut, kedua indikator ini (adjusted $\mathrm{R}^{2}$ dan F-stat) ternyata memiliki nilai yang paling rendah dibandingkan dengan persamaan estimasi 15 variabel kinerja lainnya.Secara singkat bisa disimpulkan, bahwa k_14 tidak bisa dijadikan patokan dalam mengukur kinerja keuangan daerah.

Dalam hal kontribusi f_07 yang membuka adanya heterosedastisitas (pelangaran aumsi klasik) pada persamaan estimasi abs_rk15 (indikator elastisitas APBD, rasio belanja langsung terhadap PAD), hal ini menegaskan keberadaan f_07 atau Celah Fiskal I (selisih DAU formula dengan alokasi dasar/ belanja pegawai di data dasar) tidak bisa dijadikan patokan dalam mengukur kinerja keuangan daerah.

Kesimpulannya, persamaan estimasi k_14 dan variabel f_07 tidak bisa dimasukkan ke dalam analisa akhir dalam tulisan ini.

\subsection{Nilai $\mathrm{DW}$}

Regresi linier yang dilakukan terhadap data cross-section membuat uji otokorelasi kehilangan makna dan relevansi pada penelitian ini.Satu periode analisa jelas tidak menghasilkan residu per periode. Nilai DW yang tersedia di tabel pun dibatasi pada $\mathrm{n}=200$ dan $\mathrm{k}=21$. Lihat Tabel - Models with no intercept yang dikoreksi Farebrother untuk korelasi serial (positif dan negartif). ${ }^{23}$

Menurut Gujarati, asumsi homosedastisitas (kesamaan varian error) biasanya tidak bisa diharapkan pada data cross-section. Dengan kata lain, data cross-section sering mengidap heterosedastisitas. Data cross-section jelas sukar dan tidak memiliki korelasi antara variabel bebas dan kemampuan dalam memprediksi variabel yang ingin diestimasi. $^{24}$

Pun bila ada otokorelasi dalam data cross-section, korelasi yang ada bisa disebut otokorelasi ruang (spasial), bukan korelasi menurut waktu. Data yang ingin diuji pun perlu diurut secara logis, memiliki arti dan kepentingan ekonomi.

Nilai statistik DW pada studi ini berkisar antara 2,288 sampai 2,873, dengan nilai rata-rata sebesar 2,571 .

\subsection{Nilai $R$ dan $R^{2}$}

\footnotetext{
${ }^{23}$ William N. Evans, Topics in Time Series Analysis, Econometric Lecture Notes, University of Notre Dame,https://www3.nd.edu/ wevans1/econ30331/Durbin_Watson_tables.pdf

${ }^{24}$ Damodar N. Gujarati, Basic Econometrics, 4/e, McGraw-Hill, NY, 2003, hal.441.
} 
Berdasarkan rekapitulasi hasil regresi terhadap 16 variabel kinerja, kemandirian (k_08) menempati peringkat pertama sebagai persamaan dengan GoF (goodness of fit) tertinggi, yakni dengan $\mathrm{R}$ sebesar 0,999.Celah Fiskal III (f_09) dan pengeluaran pembiayaan (f_03) merupakan 2 determinan utama dalam memprediksi ukuran kemandirian (k_08) keuangan daerah.Ketika hanya f_09 berfungsi sebagai prediktor k_08, nilai R-nya mencapai 0,881; sementara bersama f_03, kemampuan f_09 untuk memprediksi k_08 mampu mencapai R ke level 0,909.

Tabel - Ringkasan regresi linier (OLS) dengan 16 variabel terikat

\begin{tabular}{|c|c|c|c|c|c|c|c|}
\hline Var. Terikat & $\mathrm{R}$ & $\mathrm{R}^{2}$ & $\operatorname{Adj} R^{2}$ & SE est & DW & $\mathrm{F}$ & $\operatorname{sig} \mathrm{F}$ \\
\hline $\mathrm{k} \_01$ & 0.991 & 0.982 & 0.848 & 9.76289 & 2.288 & 7.336 & 0.032 \\
\hline k_02 & 0.992 & 0.983 & 0.862 & 1.54350 & 2.344 & 8.090 & 0.027 \\
\hline k_03 & 0.955 & 0.911 & 0.267 & 7.36793 & 2.843 & 1.414 & 0.407 \\
\hline k_04 & 0.954 & 0.911 & 0.263 & 7.59444 & 2.873 & 1.406 & 0.409 \\
\hline k_05 & 0.971 & 0.944 & 0.535 & 7.05516 & 2.713 & 2.311 & 0.216 \\
\hline k_06 & 0.980 & 0.961 & 0.681 & 6.61052 & 2.504 & 3.431 & 0.119 \\
\hline k_07 & 0.979 & 0.959 & 0.658 & 8.21752 & 2.469 & 3.189 & 0.133 \\
\hline k_08 & 0.999 & 0.998 & 0.980 & 6.24950 & 2.812 & 55.686 & 0.001 \\
\hline k_09 & 0.990 & 0.980 & 0.838 & 7.19848 & 2.388 & 6.869 & 0.037 \\
\hline k_10 & 0.996 & 0.993 & 0.939 & 3.34270 & 2.724 & 18.595 & 0.006 \\
\hline k_11 & 0.957 & 0.916 & 0.307 & 23.23300 & 2.521 & 1.504 & 0.378 \\
\hline $\mathrm{k} \_12$ & 0.994 & 0.988 & 0.898 & 3.63343 & 2.658 & 11.012 & 0.015 \\
\hline $\mathrm{k} \_13$ & 0.995 & 0.989 & 0.913 & 7.79746 & 2.581 & 12.940 & 0.011 \\
\hline $\mathrm{k} \_14$ & 0.841 & 0.707 & -1.418 & 14.23636 & 2.323 & 0.333 & 0.966 \\
\hline k_15 & 0.996 & 0.992 & 0.931 & 64.05097 & 2.367 & 16.305 & 0.007 \\
\hline $\mathrm{k} \_16$ & 0.997 & 0.995 & 0.957 & 0.46366 & 2.722 & 26.117 & 0.003 \\
\hline
\end{tabular}

Peringkat kedua ditempati persamaan dengan rasio DAU dalam TKDD terhadap DAU Formula (k_16) sebagai variabel terikat dengan R sebesar 0,997.Peringkat ketiga ditempati persamaan dengan desentralisasi (k_10) sebagai variabel terikat dengan $\mathrm{R}$ sebesar 0,996 dan $\mathrm{R}^{2}$ sebesar 0,993. Khusus untuk variabel desentralisasi (k_10), regresi determinasi menghasilkan 6 persamaan estimasi yang terbagi kedalam 2 kelompok, yakni yang melibatkan 3 variabel bebas dan 4 variabel bebas.y_03 dan y_06 merupakan 2 variabel determinan yang muncul di 5 dari ke-6 persamaan ini. y_03 merupakan data PAD <APBD>, sementara y_6 merupakan data Dana Perimbangan <APBD>.

Pada persamaan estimasi k_10 dengan 3 variabel bebas, nilai $\mathrm{R}$ bersifat inkremental, yakni dari hanya variabel bebas f_09 $(\mathrm{R}=0,832)$, bersama variabel y_03 $(\mathrm{R}=0,859)$, dan bertiga bersama variabel y_06 $(\mathrm{R}=0,900)$.

Pada persamaan estimasi k_10 dengan 4 variabel bebas, nilai $\mathrm{R}$ bersifat inkremental, yakni dari 2 variabel bebas pertama (y_03 dan y_06) yang sangat mendeterminasi pada level 0,900.Dua variabel bebas lainnya yang mampu 
mendeterminasi adalah y_02 dan y_10.Tiga variabel bebas pertama, (y_03, y_06, y_02), mampu menghasilkan nilai $\mathrm{R}$ ke level 0,921. Bersama variabel bebas keempat (y_10), persamaan yang ingin diestimasi mampu menghasilkan $\mathrm{R}$ ke level 0,935.

Akan halnya nilai Adj $\mathrm{R}^{2}$ yang kecil dan dihipotesakan tidak memiliki koefisien determinasi, Tabel - Ringkasan Regresi Determinasi memperlihatkan 3 dari 4 persamaan yang ingin diestimasi terbukti tidak memiliki koefisien yang mendeterminasi, yakni pada persamaan yang mengestimasi nilai pertumbuhan PAD(k_14), skor Kesehatan Fiskal dan Pengelolaan Keuangan Daerah (k_03), dan efektivitas (k_11).

Khusus untuk infrastruktur (k_04), pada regresi linier (OLS), variabel luas daratan (r_02) termasuk 30 variabel yang dikecualikan dalam mengestimasi.Ketika regresi determinasi dilakukan, variabel luas daratan (r_02) merupakan determinan utama yang mampu memprediksi variabel infrastruktur (k_04).Variabel kedua yang bisa mendeterminasi dalam estimasi k_04 adalah aspek pengeluaran pembiayaan (f_03).Ketika hanya r_02 berfungsi sebagai prediktor k_04, nilai R-nya mencapai 0,448; sementara bersama f_03, r_02 mampu mencapai R sampai 0,614.

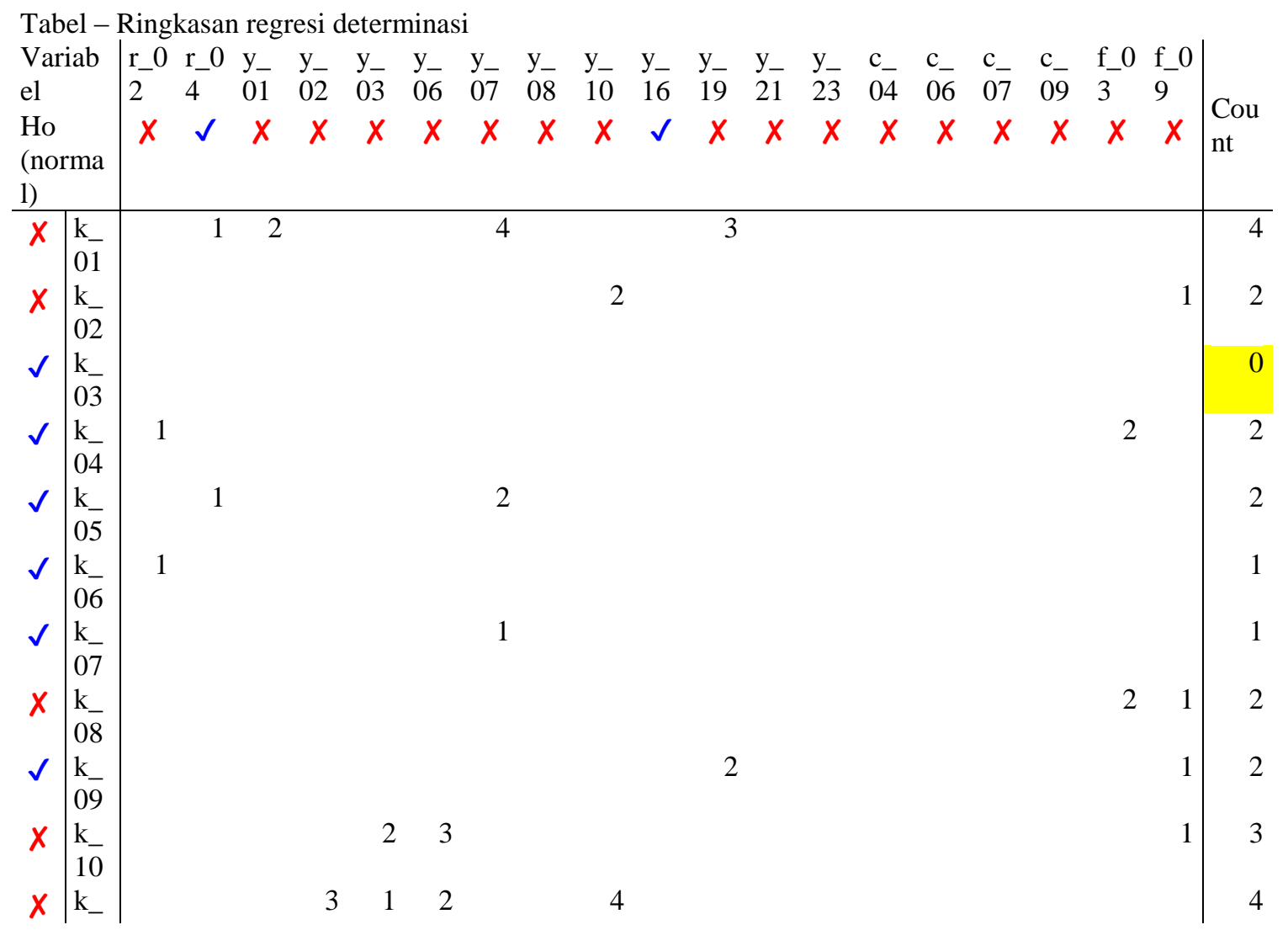




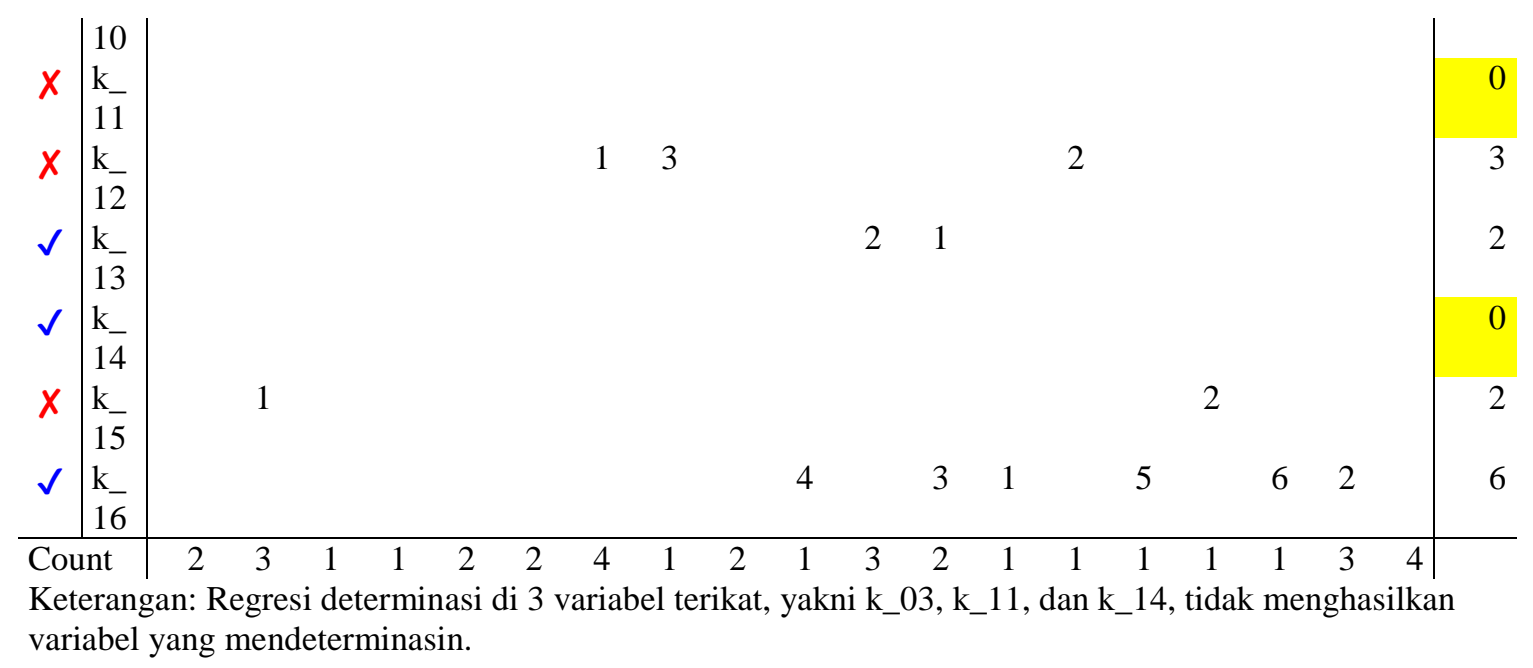

Bila kita melihat pada ketiadaan variabel bebas yang bisa mendeterminasi variabel kinerja keuangan daerah, kita dapat menyimpulkan bahwa 3 dari 16 variabel terikat, yakni k_03, k_11, dan k_14, tidak bisa dijadikan ukuran kinerja keuangan daerah. Secara verbal dan definitif, ketiga variabel kinerja keuangan daerah tersebut adalah indikator kinerja Kesehatan Fiskal \& Pengelolaan Keuangan Daerah (k_03), efektivitas (k_11, rasio PAD yang terealisasi dan target), dan pertumbuhan PAD (k_14).

k_16 (rasio DAU dalam TKDD terhadap DAU formula) menjadi variabel kinerja keuangan daerah dengan jumlah determinan terbanyak, yakni 6 dari 48 variabel bebas.Pada saat regresi determinasi, sebanyak 19 variabel bebas dikecualikan oleh SPPS. Ke-19 variabel bebas yang dikecualikan adalah r_04, y_03, y_05, y_06, y_08, y_09, y_15, y_21, y_22, y_23, c_01, c_03, c_05, f_02, f_04, f_05, f_06, f_10, dan f_11.

Dari 29 variabel bebas yang diestimasi bisa memprediksi variabel kinerja keuangan daerah, hanya 19 saja yang bisa mendeterminasi, sementara 10 variabel bebas lainnya tidak bisa memiliki kemampuan untuk mendeterminasi. Ke-19 variabel bebas yang bisa mendeterminasi terdiri dari r_02, r_04, y_01, y_02, y_03, y_06, y_07, y_08, y_10, y_16, y_19, y_21, y_23, c_04, c_06, c_07, c_09, f_03, dan f_09.

Dari ke-19 variabel bebas yang bisa mendeterminasi, hanya 2 variabel bebas, yakni y_07 dan f_09, yang mampu mendeterminasi sampai 4 variabel kinerja keuangan daerah.Variabel bebas y_02 berperan mendeterminasi di 4 variabel kinerja keuangan daerah, yakni k_12, k_07, k_05, dan k_01.Variabel bebas f_09 berperan mendeterminasi di 4 variabel kinerja keuangan daerah, yakni k_02, k_08, k_09, dan k_10. 


\subsection{Penutup}

Berbagai indikator kinerja keuangan daerah dari beberapa studi terkait dikompilasi ke dalam tulisan ini.Beberapa rumusan dan variabel yang dipakai dan diterapkan pada studi terdahulu ternyata tidak bisa diterapkan dalam studi ini.Ketidakjelasan definisi operasional dan sumber data merupakan 2 penyebab utama tidak bisa dipakainya beberapa rumusan dan variabel penting seperti penghitungan kebutuhan fiskal, kapasitas fiskal, celah fiskal, dan lainnya.

Ketidakjelasan nampak terlihat pada beberapa hal berikut, antara lain:

1. Berbedanya nilai DAU pada 3 sumber data di DJPK, yakni data dasar, TKDD, dan APBD.

2. Definisi TBR (total belanja rata-rata) yang tidak jelas dan tidak konsisten.

a. Pada penghitungan DAU Formula di tahun 2018, TBR dihitung berdasar data belanja daerah dari laporan realisasi APBD TA 2016 yang disampaikan daerah kepada Kementerian Keuangan atau proyeksi realisasi APBD TA 2016.

b. Pada penghitungan DAU Formula di tahun 2017, TBR dihitung berdasarkan data belanja daerah yang bersumber dari pemda provinsi dan kabupaten/kota dengan mempertimbangkan beban pengalihan urusan pendidikan SMA/SMK dan urusan lainnya dari kabupaten/kota ke provinsi.

3. Dasar dan logika perubahan pembobotan berbagai indeks dalam penghitungan variabel kebutuhan fiskal di tahun 2018 dibandingkan 2 tahun sebelumnya. Beberapa indeks yang dimaksud meliputi indeks penduduk, wilayah, kelautan, pembangunan manusia, kemahalan konstruksi, dan PDRB per kapita.

4. Dasar dan logika perubahan pembobotan penghitungan alokasi dasar dan celah fiskal tahun 2018 dibandingkan 2 tahun sebelumnya.

5. Tidak adanya informasi terkait kebijakan dana transfer umum untuk TA 2018 seperti yang tertulis untuk (atau dalam Undang-Undang) APBN TA 2017.

Sesuai Permenkeu No.48/PMK.07/2016, dalam UU APBN TA 2017, dana transfer umum (DTU) diarahkan lebih dari atau sama dengan 25\% untuk belanja infrastruktur daerah yang langsung terkait dengan percepatan pembangunan fasilitas pelayanan publik dan ekonomi dalam rangka:

1. meningkatkan kesempatan kerja,

2. mengurangi kemiskinan, dan 
3. mengurangi kesenjangan penyediaan layanan publik antar daerah.

\section{SIMPULAN}

Dari 13 indikator kinerja keuangan daerah yang bisa dan berhasil dikompilasi ke dalam tulisan ini, dan mengacu pada sumber data dari situs DJPK, sebanyak 16 variabel kinerja keuangan pemerintah daerah berhasil didefinisikan. Empat kelompok variabel pembentuk APBD ditetapkan memiliki peran dalam mengestimasi dan memprediksi variabel kinerja keuangan daerah.

Keempat kelompok variabel tersebut mencakup unsur wilayah (luas dan penduduk), penerimaan, pengeluaran (belanja), dan pembiayaan/fiskal. Unsur wilayah (r, region) terbagi atas 4 variabel, unsur penerimaan terbagi atas 23 variabel, unsur (pengeluaran) belanja terbagi atas 9 variabel, dan unsur pembiayaan/fiskal terbagi atas 12 variabel. Secara keseluruhan, 48 variabel bebas digunakan untuk mengestimasi dan memprediksi 16 variabel kinerja keuangan daerah.

Dalam proses regresi linier OLS, sebanyak 19 variabel bebas dikecualikan, antara lain r_02, y_03, y_05, y_06, y_09, y_10, y_15, y_23, c_01, c_03, c_05, c_07, f_02, f_04, f_05, f_06, f_07, f_10, dan f_11. Dalam proses regresi determinasi, dengan nilai residual dari regresi OLS yang diabsolutkan dan dijadikan variabel terikatnya, sebanyak 19 variabel bebas yang dikecualikan meliputi r_04, y_03, y_05, y_06, y_08, y_09, y_15, y_21, y_22, y_23, c_01, c_03, c_05, f_02, f_04, f_05, f_06, f_10, dan f_11.

Dari proses regresi linier OLS, sebanyak 3 variabel kinerja keuangan daerah yang paling signifikan diprediksi adalah kemandirian (k_08), rasio DAU dalam TKDD terhadap DAU Formula (k_16), dan desentralisasi (k_10). Mengacu pada nilai adusted $\mathrm{R}^{2}$ yang minim, yakni kurang dari 0,3, sebanyak 4 variabel kinerja keuangan daerah lainnya ditengarai tidak bisa diprediksi dengan baik, yakni k_14, k_04, k_03, dan k_11.

Sementara dalam proses regresi determinasi, sebanyak 3 variabel kinerja keuangan pemerintah daerah tidak memiliki koefisien yang bisa mendeterminasi, yakni k_14, k_03, dan k_11. Ketiga variabel kinerja ini merupakan bagian dari 4 variabel kinerja dengan nilai adjusted $\mathrm{R}^{2}$ yang minim.

Berdasarkan uji statistik untuk melihat ada/tidaknya heterosedastisitas sebagai bentuk penyimpangan asumsi klasik, definisi variabel k_14 dalam tulisan ini tidak bisa dijadikan sebagai patokan dan acuan ukuran kinerja keuangan pemerintah 
daerah.Demikian pula untuk definisi variabel $\mathrm{f} \_07$ dalam tulisan ini tidak bisa dijadikan sebagai patokan dan acuan ukuran variabel pembiayaan/fiskal daerah.

\subsection{Keterbatasan}

Penelitian ini hanya menggunakan data dari situs DJPK, yang hanya memberikan 2 periode waktu pelaporan APBD, yakni 2018 dan 2019. Sementara data historis lainnya disajikan dalam bentuk file Microsoft Excel. Persebaran dan distribusi file yang di-upload ke situs DJPK bersifat insidentil dengan cut-off date yang berbeda per satuan waktu pelaporan.

Data yang ada di situs DJPK bersifat sementara.Beberapa diantaranya masih berstatus dalam tahap verifikasi dan konfirmasi.Data yang ada pun bersumber dari dokumen yang dikirim daerah ke DJPK.

Beberapa keterbatasan lainnya dari penelitian ini adalah sebagai berikut:

1. Penelitian ini tidak menggunakan sumber data lainnya seperti BPS, Bank Indonesia, atau lainnya.

2. Penelitian ini tidak pula memberikan deskripsi kualitatif menurut provinsi dan indikator kinerja serta variabel pembentuk APBD.

3. Penelitian ini tidak pula memberikan deskripsi APBD dalam bentuk rancangan, undang-undang, maupun realisasinya.

4. Penelitian ini tidak pula memberikan deskripsi kekuatan dan kelemahan serta daya saing APBD.

5. Penelitian ini tidak pula memberikan cara, rencana, strategi, manajemen perbaikan struktur APBD, atau lainnya dalam rangka peningkatan kinerja keuangan daerah.

\subsection{Rekomendasi}

Terlepas dari keberadaan 16 variabel kinerja keuangan pemerintah daerah yang berhasil diidentifikasi dan didefinisikan, ada beberapa variabel kinerja lainnya yang memiliki nilai ya (1) dan tidak (0). Proses regresinya pun bersifat tersendiri, yakni menggunakan metode atau model regresi respon kualitatif. Tiga model yang umum adalah LPM (linear probability model), logit (logistik), dan probit (normit).

Beberapa variabel kinerja keuangan daerah yang memiliki nilai diskrit adalah sebagai berikut:

1. Opini BPK atas LKPD.

2. Ketepatan waktu penetapan Perda APBD. 
3. Penggunaan e-procurement.

4. Penggunaan e-budgeting.

5. Ketersediaan PTSP.

6. Pemenuhan Kriteria Utama.

7. Inovasi Pelayanan Publik.

8. Kemudahan Investasi.

9. Kemudahan Berusaha.

10. Pengelolaan Sampah.

11. Penyelenggaraan Pemerintahan.

12. Perencanaan Daerah.

13. Sistem Akuntabilitas Kinerja Instansi Pemerintah (SAKIP).

Ke-13 variabel kinerja yang memiliki nilai diskrit ini bisa memberi tambahan 27 variabel dependent yang bisa diestimasi dan diprediksi, yakni dengan menterjemahkannya ke bentuk variabel dummy.

Beberapa data historis terkait APBD menurut satuan waktu dan Dati II sangat memungkinkan untuk ditelusuri lebih lanjut ke penelitian selanjutnya yang lebih kompleks dan komprehensif.

\section{DAFTAR PUSTAKA}

Abdul Halim, Bunga Rampai Manajemen Keuangan Daerah. AMP YKPN.Yogyakarta, 2001.

Abdul Halim. Akuntansi Sektor Publik Akuntansi Keuangan Daerah, Salemba Empat. Jakarta. 2004.

Adrika Fardisa Maskuna, Abd. Kodir Djaelani, dan M. Khoirul ABS. Analisis Pengaruh Anggaran Pendapatan dan Belanja Daerah (APBD) terhadap Kinerja Keuangan Pemerintah Daerah Kota Blitar Tahun 2011-2015, Universitas Islam Malang, 20170809.

Anwar Shah dan Zia Qureshi, Intergovernmental Fiscal Relation in Indonesia: Issues and Reform Option, Discussion Paper, World Bank, 1994:49-53. 
Aswin Rizkiano, Pengukuran Tingkat Kemampuan Keuangan Daerah dalam Mendukung Pelaksanaan Otonomi Daerah Periode 2004-2008 di Kota Salatiga, 20110419.

Balitbang Depdagri - Fisipol UGM, Pengukuran Kemampuan Keuangan Daerah Tingkat II dalam Rangka Otonomi Daerah Yang Nyata dan Bertanggung Jawab, Jakarta, 1991.

BAPPENAS. Peta Kemampuan Keuangan Provinsi dalam Era Otonomi Daerah:

Tinjauan Atas Kinerja PAD dan Upaya yang Dilakukan Daerah. Direktorat Pengembangan Otonomi Daerah. 2003.

Departemen Dalam Negeri Republik Indonesia, Manual Administrasi Keuangan Daerah, Jakarta. 1991.

Haryo Kuncoro, Variansi Anggaran dan Realisasi Anggaran Belanja Studi Kasus Pemerintah Daerah Provinsi DKI Jakarta, Jurnal Manajemen Teori dan Terapan, Vol.1, No.2, Agustus 2008.

Hery Susanto, Analisis Perkembangan Kinerja Keuangan Daerah dalam Upaya

Mendukung Pelaksanaan Otonomi Daerah di Propinsi Nusa Tenggara Barat, 2003-2007, FE Universitas Terbuka, 2008.

I Dewa Gde Bisma dan Hery Susanto, Evaluasi Kinerja Keuangan Daerah Pemerintah Provinsi Nusa Tenggara Barat Tahun Anggaran 2003 - 2007, GaneÇ Swara, Edisi Khusus, Vol.4, No.3, Des. 2010.

Indah Yuliani Mone, Rahardjo Adisasmita, Mediaty, Pengaruh Pengelolaan Keuangan Daerah terhadap Kinerja Ekonomi Daerah di Kabupaten Pangkep, 2003-2012, 20131127.

M. Bugis dan Bin Raudha A. Hanoeboen, Analisis Tata Kelola Anggaran Pendapatan dan Belanja Daerah Kabupaten Maluku Tengah, 20170526.

Mardiasmo. Akuntansi Sektor Publik. Andi.Yogyakarta. 2002.

Mardiasmo.Otonomi Daerah dan Manajemen Keuangan Daerah.Andi.Yogyakarta. 2002.

Maria Rosarie Harni Triastuti, Muhadjir Darwin, dan Ratminto, Analisis Kemandirian Keuangan Daerah Kota Yogyakarta (Studi tentang Desentralisasi dan Otonomi Fiskal Daerah), Sosiosains, 18 (2), April 2005.

Mohamad Mahsun. Pengukuran Kinerja Sektor Publik. BPFE, Yogyakarta, 2006. 
Pandu Cahya Nugraha, Analisa Index Perhitungan Ratio Anggaran Pendapatan dan Belanja Daerah (APBD) Kabupaten Kulonprogo Yogyakarta Periode Tahun 2007 sampai dengan 2011, Jurnal Perilaku dan Strategi Bisnis, Vol.5, No.1, 2017, hal.94-108.

R. Agoes Kamaroellah, Analisis Kinerja Pengelolaan Anggara Pendapatan dan Belanja

Daerah pada Badan Keuangan Daerah Kabupaten Pamekasan. Laporan Penelitian, Sekolah Tinggi Agama Islam Negeri Pamekasan. 2017.

Ramliyanto, Penyusunan Indikator Kinerja Utama (IKU), 20131210.

Rudy Badrudin, Pengaruh Desentralisasi Fiskal terhadap Belanja Modal, Pertumbuhan

Ekonomi, dan Kesejahteraan Masyarakat Kabupaten/Kota di Provinsi Jawa Tengah, Disertasi, Program Pasca Sarjana, Universitas Airlangga, Surabaya, 2012.

Ruslina Nadeak (Agnes Jeanette Nadeak), Analisis Rasio Keuangan APBD untuk Menilai Kinerja Pemerintah Daerah: Kasus pada Kabupaten Maluku Tenggara, Skripsi, Universitas Sanata Dharma, Yogyakarta, 2003.

Satija, Muhadjir Darwin, dan Ratminto, Kapasitas Keuangan Daerah Kabupaten Sleman, Sosiosains, 19 (3) Juli 2006.

Silviana dan Melisa, Analisis Kinerja Keuangan Pemerintah Kota Bandung Tahun 2008-2012, Profita, Vol.6, No.3, Des. 2014.

Sukanto Reksohadiprodjo, Ekonomika Publik, BPFE Yogyakarta. 2001.

Yuliana, Analisis Kinerja Anggaran Pendapatan dan Belanja (APBD) Ditinjau Dari Rasio Keuangan (Studi Kasus di Kabupaten Sragen Periode 2010-2012), Skripsi, Fak.Ekonomi dan Bisnis, Universitas Muhammadiyah Surakarta, 2013.

\section{Peraturan}

UU No.33/2004 tentang PKPD (Perimbangan Keuangan antara Pemerintah Pusat dan Pemerintahan Daerah)

UU No.32/2004 tentang Pemda

UU No.22/1999 tentang Pemda

UU No.5/1979 tentang Pemerintahan Desa (LN 1979 No.56, TLN No.3153)

UU No.5/1974 tentang Pokok-Pokok Pemerintahan di Daerah (LN 1974 No.38, TLN No.3037) 
UU No.19/1965 tentang Desapraja sebagai Bentuk Peralihan untuk Mempercepat Terwujudnya Dati III di Seluruh Wilayah RI.

Peraturan Menteri Dalam Negeri No.13/2006 tentang Pedoman Pengelolaan Keuangan Daerah.

Peraturan Menteri Dalam Negeri No.59/2007 tentang Perubahan atas Permendagri No.13/2006. 